problem is in trying to prevent and correct forms of social insecurity that are felt to be increasing so that at the same time we can use our varying resources to support population growth, conserve society's labor resources, and further the sensible use of resources from the point of view of society.

\title{
Housing Policy and Population Development
}

By AARNO STRÖMMER

National Housing Board

A low birthrate and emigration to Sweden are two of the current national problems in Finland. Inadequate housing facilities can be found among the causes of both problems.

Thus, for example, it is noted in the national housing program for the 10year period of 1976-85 that the housing problems of young families, especially the high cost of housing, can be seen as one of the reasons why Finland's birthrate is one of the lowest in Europe. On the other hand, in questionnaires connected with emigration there are always some respondents, very few though actually, who name poor housing facilities as their primary reason for moving to Sweden. Most respondents, of course, point to to unemployment at home and better opportunities for making a living in Sweden.

It is not easy to prove through research how big a part inadequate housing facilities have played in the negative aspects of population development. On the contrary, one wonders how things might have developed without the rather considerable improvement in housing facilities, which has been a notable factor in the social development of the »building decades» after World War II in Finland also.

By comparing statistics it has been shown that Finnish housing investments compared to national income have reached international peaks for quite some time. The northern location of the country and the additional demands this places on construction are obvious contributing factors here. On the other hand it was necessary for Finland after the war to supply housing for her Karelian evacuees, almost half a million strong. Later on the country has gone through a social structure change which has signified active regional mobility of the population. One of the main results has been that industries other than agriculture and forestry have risen from 50 percent of the whole population to almost 90 percent at the moment.

As the result of a vigorous building program, and despite the rather large amount of existing housing eliminated from use, the overall housing supply of 
the country has increased from a scant million in 1950 to 1.7 million in 1977 or from 25 housing units per 100 residents to 36 per 100 . Since the average number of rooms per housing unit has also increased, living space has significantly expanded: the number of rooms per 100 residents is 110 while a generation ago it was only 65 .

Nevertheless, the situation is still considered unsatisfactory. It is especially so when compared to the rest of Scandinavia: in 1970 Sweden had 146 rooms per 100 residents, Norway had 149 and Denmark had 164 (Finland had 99.) As a matter of fact, one fifth of all households in Finland had in that year more than two people per room (not counting the kitchen as a room). This kind of cramped housing hardly existed in the other Nordic countries.

Thus one of the basic goals of Finnish housing policy in the near future will be to gradually eliminate overcrowding by emphasizing the need for more spacious family housing units both in new housing production and in the basic renovation of old houses, which has become increasingly more important in the renewal of the housing supply. From the standpoint of succesful family policy it is important to note the attention given to housing environment problems, which have surfaced during the years of abundant building now behind us. As a result a move towards making it possible to build more one-family houses has been made in the production goals for the 10-year period of 1976-85. According to these goals the percentage of one-family and row houses in new building projects should rise from the $40-45$ percent level up to 60 percent before the end of the period. There seems to be a realistic basis for bettering the quality of housing in answer to increasing demands, meaning that it should be within the means of the national economy, as soon as the quota of needed housing units has been reached. While the national building program for the years 1966-75 was still rising (from 40000 to 60000 housing units per year), the new 10-year program shows a marked decline. Naturally the reasons for this declining need can be found in the halt in total population growth and also in the expectation of a general equilibrium in regional development, which tends to restrain internal migration or at least to lessen the effect it has on the need for new housing.

The main forms of housing policy support paid by Finnish society are longterm and low-interest government loans for new building projects and, for residents in this housing, support for paying interest on these loans, certain tax reductions plus direct housing allowances. In these forms of support family policy viewpoints are most prominent in the government building-loan and housing-allowance systems.

About 30 percent of the country's 600000 rental units and a little more than 30 percent of the 1.1 million resident-owned dwellings are financed by government loans. These percentages are still rising, for over half of the new housing built each year is financed by government loans - and thus also comes under the price and quality control exercized by the housing authorities. Loans for 
rental units are granted for the entire real-estate and are limited to 60 percent of building costs.

Loans for buying a residence - whether it is a one-family house or an apartment in an apartment building or row house - are at present granted mainly for the individual dwelling unit and their amount is $10-60$ percent of building costs, depending on the size and income of the family. In accepting residents for housing financed by government loans, certain income limits are used, which rose according to the size of the family.

When selecting residents for both rental and ownership units certain rules pertaining to living space are also observed. There should be no more than two people per room (the kitchen is not counted as a room), neither should there be less than one person per room. An unborn child is also counted as a family member, if a doctor's certificate of pregnancy can be shown. If there is no such certificate, a childless newlywed couple cannot be given a family dwelling proper, that is a unit of at least three rooms and a kitchen. Finland's central organization for family welfare policy has made continuing protests against this kind of seggs first, then the nest» principle.

Under the general housing allowance system, as it was renewed in 1975, housing support is granted to families with children whose income falls below income limits scaled according to the size of the family. This support is given to families in rental housing and, in addition, to those who own their own dwellings if these owned dwellings were built in or after 1974. In this system it is not necessary to have seggs» since housing allowance is also given to childless couples, if both were under 30 at the time of marriage. In this case support is paid for the year the marriage took place and for the two following years. If the couple has a child during this period, the size of the support will be adjusted accordingly.

It is estimated that the renewed housing allowance system will be a significant factor in reducing the housing expenses of young families with children. How significant depends decisively on matters of national economy, that is on the amount of funds that can be designated for this purpose. During the middle of 1977 there were about 65000 families receiving support, and this number is still rising. In 1976 housing expenses would have used up 25.6 percent of the income of families receiving support, if they had not received housing support. Because of this support housing expenses stayed at a reasonable 13.0 percent.

In relating housing policy to population development there is also the question of directing regional housing production according to the goals set for the general development of society. In Finland government building loans are mostly channelled according to quotas set each year for each province by the Council of State. These in turn are based on estimated housing needs, which are derived from starget forecasts» that the Council of State checks periodically for regional developments in available jobs and growth of the population. 